\title{
Reforming Crown Copyright in Canada
}

\author{
Amanda Wakaruk
}

$\mathbf{T}$ he public domain status of US federal government works has been a point of envy for librarians working in Commonwealth countries for more than a century. ${ }^{1}$ Absent of the constructed barriers of copyright controls, anyone is able to freely reproduce, share, and build upon US federal government publications. This results in greater distribution, and thus greater visibility and impact, for the expertise of federal employees including scientists, policy analysts, and statisticians. It also helps prevent copyright chill, which occurs when legitimate rights are not exercised due to a fear of infringement, real or imagined. ${ }^{2}$

Conversely, copyright controls over Canadian government publications were added to the Copyright Act of 1921, having been essentially 'copied and pasted' from language in the 1911 UK legislation. ${ }^{3}$ Section 12 provides the government with control over the re-use and distribution of government works, despite the fact that the production of such works does not require the economic incentivization that the Act was designed to provide. Furthermore, any necessary non-economic controls are now rendered via the Access to Information Act, enacted more than 30 years ago (in 1983), and the Treasury Board Secretariat Policy on Communications and Federal Identity. ${ }^{4}$

For the past 100 years, Canadians have had to ask for permission to re-use and distribute government works or risk facing a claim of copyright infringement. Even if we can ignore the fact that there are no morally compelling arguments for the government to profit off works paid for by the populace, we might at least reasonably expect that the administration of such controls would be in the public interest. Unfortunately, evidence to support this stance is lacking.

Prior to November 2013, the granting of permissions to use government publications was managed by a centralized service known as "Crown Copyright and Licensing" (CCL). The cessation of this service, and subsequent downloading of this function to federal 'author' agencies, was one of many cutbacks and closures that negatively affected access to government information in Canada between 2010-2015. 'While far from acting as a preventative for copyright chill, CCL did provide a centralized point of contact for users. Its closure exacerbated confusion around Crown copyright, as staff in author agencies rarely received the necessary training and many requests were for materials produced by agencies that no longer existed (i.e., no 'author' was available to provide permissions). To make matters worse, web-based government content was being removed without comprehensive archiving and alternative access points. More egregiously, requests from librarians to capture and redistribute these materials via web-based platforms were often ignored and sometimes denied. ${ }^{6}$

Government information librarians and libraries outside of government agencies have been acting as stewards of government information in service to democratic nations for generations. In Canada, the mishandling of Crown copyright is preventing these efforts and potentially enabling an environment of censorship.

Evidence and arguments against the need for Crown copyright, as well as examples of the barriers created by the current regime in Canada, were collected and presented to the House of Commons as an official petition in October 2017, with almost 1,500 verified signatories (almost three times the required threshold for tabling in parliament). ${ }^{7}$ The petition asked that copyright controls be removed from government works made available to the public. The government responses to the petition cited concerns related to cost recovery as well as accuracy and quality. ${ }^{8}$ This is a confusing response for those familiar with copyright, as accuracy and quality are not included in the bundle of rights provided through copyright legislation. Furthermore, the very nature of cost recovery implies that such publications could be made available without barriers once the costs were recovered. The government responses, submitted in December 2017, also noted the upcoming statutory Copyright Act review, where parliamentarians would have an opportunity to review all provisions of the statute. 


\section{Copyright Act Review of 2018 / 2019}

In March 2018, the House of Commons Standing Committee on Industry, Science and Technology began its scheduled review of the Copyright Act. The committee received written submissions and oral testimony from invited experts and interested members of the public on a wide range of issues. At least twentyone of the 192 written submissions asked that Crown copyright be abolished or reformed. In addition, nineteen witnesses made statements or fielded questions from Members of Parliament about Crown copyright during the committee's proceedings.'

Multiple associations from the library and archival communities weighed in on the issue of Crown copyright as part of the review. Here are the related recommendations from the three largest of such organizations:

Canadian Federation of Library Associations (CFLA, formerly Canadian Library Association), https://www.ourcom mons.ca/Content/Committee/421/INDU/Brief/BR9921734 /br-external/CanadianFederationOfLibraryAssociations-e.pdf

Recommends that Parliament eliminate Crown copyright on all publicly accessible government works or make those works openly licensed by default and examine section 12 to clarify the need for Crown copyright in other government works.

Canadian Association of Research Libraries, https://www .ourcommons.ca/Content/Committee/421/INDU/Brief /BR10003061/br-external/CanadianAssociationOfResearch Libraries-e.pdf

Recommendation: Take steps towards the waiver or elimination of Crown copyright by consistently applying an open license regime to Crown material, or by amending the Act to effectively abolish Crown copyright.

Canadian Council of Archives, https://www.ourcommons .ca/Content/Committee/421/INDU/Brief/BR10008890/br -external/CanadianCouncilOfArchives-e.pdf

At a minimum, we recommend that the Act be amended immediately to establish that copyright in Crown works lasts for fifty years from date of creation, regardless of whether or not they are published. We further recommend that the federal government commission a comprehensive study that will identify the ways that Crown copyright is currently addressed by various levels of government, identify the many problematic issues, explore the solutions adopted by other countries, consult with stakeholders, and recommend appropriate measures that will transform this outdated provision into a measure that serves the public interest in the digital age.
There is no question that librarians and archivists played a major role in the proceedings related to Crown copyright, although not all were practising government information professionals. For example, Kelsey Merkley, a librarian by training but representing Creative Commons Canada testified that, "Canada should reform Crown copyright regime, because all Canadians should have the right to access and reuse, without restriction, work produced by their government. Canada should place these materials directly into the public domain at the time of publishing." 10 Also, both Jean Dryden, copyright consultant and independent scholar and Nancy Merrelli, special copyright advisor to the Canadian Council of Archives, noted the longstanding demand for reform of this provision, dating back to at least the 1970 s. $^{11}$

As with all things, timing can be important, and this seemed true on at least two points related to the Copyright Act review. First, the United States-Mexico-Canada trade agreement, which includes a chapter dealing with intellectual assets and copyright, was in the midst of heated negotiations (and later signed in November 2018). The trade agreement requires increased alignment on copyright provisions in Canada and the US, including the length of copyright terms (Canada will need to lengthen its term by 20 years to comply). However, there remains a radically different approach to the treatment of copyright in government works in the two countries, one that disadvantages Canadian government publications. While the real-world effects of this disconnect were noted by Wikimedia Canada during parliamentary proceedings and more broadly by both the Canadian Association of Research Libraries and the Canadian Association of Law Libraries in their written submissions, no mention of this incongruity was mentioned in the final parliamentary report. ${ }^{12}$

Secondly, parliamentarians and other interested parties working on the final report were writing in anticipation of a Supreme Court of Canada decision, Keatley v. Teranet, that would address Crown copyright as it relates to the transfer of ownership in land surveys submitted to the government. This would be the first time in the court's history to interpret section 12 of the Act. Unfortunately, the court decision was released after the parliamentary report as the latter was drafted with assumptions about the former, resulting in what appears to be contradictions in the report itself, as shown in these paragraphs leading up to the recommendation:

The Keatley Surveying case reveals that Crown copyright serves two distinct functions. The first function is to assert ownership over works prepared and published by or under the direction or control of 
Canadian governments. The second function allows Canadian governments to disseminate works they do not own for policy purposes, sometimes through private-public partnerships, and without having to request the authorization to do so. Section 12 of the Act must therefore be reviewed with both functions in mind.

The rationale under which Canadian governments would exercise copyright over publicly funded works they prepare and publish in the public interest is questionable at best. The current web of licensing agreements, orders, policies, and standing practices certainly does not promote the dissemination of these essential works. Exercising copyright over governmental publications created in the public interest should be the exception rather than the rule. ${ }^{13}$

\section{Committee Report No. 16 (Final report of the Copyright Act review of 2018/2019)}

The report prepared by the lead parliamentary committee tasked with reviewing the Copyright Act was tabled on June 3, 2019. It clearly acknowledges that, on the issue of Crown copyright, "no witness supported its continuation, at least in its current form-a rare point of consensus." ${ }^{14}$ In contrast to what parliament heard and summarized, however, the associated recommendation states that the Government of Canada should improve existing Crown copyright management practices by continuing to work with the current Open Government program. To date, this program has resulted in relatively few government publications receiving an open license and the assigned license is decidedly less open than the increasingly adopted Creative Commons attribution license. ${ }^{15}$

More confounding, however, was that the section of the recommendation related to legislative change sought only to protect the government itself from potential litigation:

That the Government of Canada introduce legislation amending the Copyright Act to provide that no Canadian government or person authorized by a Canadian government infringe copyright when committing an act, either:

- Under statutory authority; or

- For the purpose of national security, public safety, or public health. ${ }^{16}$

It is worth noting that no witness or brief submitted to the committee raised the need for increasing the protections available to the government in this area. For those who have felt the chill of Crown copyright in the field, this extension of government control certainly seems to run counter to the final statement of this section of the report, "That the Crown exercise copyright protections that are reasonably in the public interest."

Surprisingly, the parliamentarians' commentary on Crown copyright did not end with the main section of the report. Appended to the report were dissenting and supplemental reports issued independently by the two main opposition parties in Canada at the time, the Conservative Party of Canada and the New Democratic Party, who are known to sit at opposite ends of the political spectrum on most issues. In this case, both reports asked for the abolishment of Crown copyright. ${ }^{17}$

\section{Keatley v. Teranet 2019 SCC 432}

The Supreme Court of Canada's decision in Keatley v. Teranet was delivered on September 26, 2019. ${ }^{18}$ The court was unanimous in affirming that the copyright in the land surveys submitted to the government, in this case, belong to the government. While it is not the court's role to question the assumptions upon which legislation is based, it is their role to interpret existing law and their treatment of section 12 bolsters the case for reform. ${ }^{19}$

The Keatley $v$. Teranet decision is unanimous but provides both majority and concurring opinions. That is, the highest court in Canada is split on how to interpret section 12, especially as it relates to the scope of Crown copyright. Specifically, there is disagreement about the criteria that should inform decisions about whether or not Crown copyright exists in a given work. The court also notes the antiquated nature of section 12, with the majority decision including the statement, "Parliament is of course free to consider updating the provision in its current review as it sees fit" (para 90). As noted by law professor Jeremy de Beer, "That language, combined with the Court's quote about this legislative monstrosity, is about as blunt as judges can be about the need for statutory reform." ${ }^{20}$

Indeed, it seems reasonable that if the country's top jurists cannot agree on the scope of Crown copyright then it is in the public interest for legislators to recraft this outdated legal provision. In short, the court decision supports a review and reform of the Crown copyright regime in Canada. And at least some parliamentarians agree.

\section{Next Steps in Advancing Change in Crown Copyright}

At the same time as the parliamentary report was being drafted in April 2019, a long-serving member of the committee and opposition Member of Parliament, Brian Masse, New 
Democratic Party, attempted to elevate the Crown copyright issue by tabling Private Member's Bill C-440 in the House of Commons, which sought to effectively abolish Crown copyright. Bill C-440 was re-introduced to parliament in February 2020 as Bill C-209. Working together on a very short timeline, librarians and archivists representing three different national organizations participated in a press conference in support of Bill C-440, on Parliament Hill in Ottawa. ${ }^{21}$

While it is unsurprising that the 2019 Bill did not pass, it is interesting to note that the previous introduction of a Private Member's Bill seeking to abolish Crown copyright, in 1993, was tabled by former Minister of Justice Robert Kaplan while his party, the Liberal Party of Canada, sat in opposition. ${ }^{22}$ It seems that only the party in power, both today and historically, is reluctant to reform Crown copyright.

In response to the parliamentary report, the Copyright Committee of the Canadian Federation of Library Associations (CFLA) drafted a letter to federal ministers responsible for copyright in August 2019. The open letter was titled, "Next steps in advancing change in Crown copyright" and asked that the Government of Canada, "consider alternatives to the recommendation regarding Crown copyright that is proposed in the INDU [parliamentary] report." Specifically, the CFLA and eight other signatories recommended further study and the "implementation of appropriate amendments that will transform this outdated provision in a way that serves the public interest in the digital age."23

In October 2019, Canadians re-elected the political party that led the 2018 / 2019 review of the Copyright Act. In December, the Liberal Party of Canada's leader, who also serves as Prime Minister, drafted mandate letters for their appointed Ministers. These letters encourage the Ministers of the Departments of Canadian Heritage and the (renamed) Department of Innovation, Science and Industry to work together to review the Copyright Act, language that implies an ongoing commitment to work started during the 2018 / 2019 review. $^{24}$

At the time of writing, a CFLA working group dedicated to Crown copyright reform continues to meet with government employees at federal ministries responsible for copyright administration. A long-overdue reappraisal of Crown copyright has been taking place in Canada because of the persistent efforts of copyright and government information professionals, frustrated and then bolstered by a case heard by Canada's highest court of appeal.

We are hopeful that permanent legislative change is forthcoming, so that the work of Canada's cultural memory stewards is no longer hampered or prevented by unnecessary copyright controls. It serves all librarians to remember that copyright legislation is a mediating factor between creators and users and, as US librarians well know, it is also legislation that is subject to lobbying pressure and, at times, exploitive overreach. If there is a warning lesson to be learned from the work of Canadian librarians and archivists, it is to understand the value of and be ready to defend the public domain status of federal US government publications.

Amanda Wakaruk (amanda.wakaruk@ualberta.ca), Copyright Librarian, University of Alberta.

\section{References}

1. US Copyright Office, Compendium of U.S. Copyright Office Practices, Third Edition, 2017, 14, https://www.copyright.gov/comp3/chap100/ch100-general-background.pdf.

2. For legal literature related to copyright chill, search "chilling effect" and copyright. For example, Rachel M. Smith, "Why Can't My Waiter Sing Happy Birthday: The Chilling Effect of Corporate Copyright Control," IDEA: The Journal of the Franklin Pierce Center for Intellectual Property 56, no. 3 (2016): 399-448.

3. For comparative and historical information about Crown copyright, see Elizabeth F. Judge, "Crown Copyright and Copyright Reform in Canada," in In the Public Interest: The Future of Canadian Copyright Law, ed. Michael Gesit (Toronto, ON: Irwin Law, 2005), https://www.irwin law.com/sites/default/files/attached/Three_05_Judge.pdf and Emily Benton, "Abolishing Canadian Crown Copyright: Why Government Documents Should Not be Subject to Copyright" (Master of Studies in Law Research Paper, August 2019, University of Ottawa), https://ir.lib .uwo.ca/mslp/7.

4. The Treasury Board Secretariat is the administrative arm of the Treasury Board of Canada and is responsible for developing policy and setting the strategic direction for government administration in relation to providing access to information (including government publishing programs), under the authority of the Financial Administration Act (R.S.C. 1985, c. F-11) and as described in their Departmental Plan.

5. For more information about the ramifications of federal budget cuts on Canadian library services, see Amanda Wakaruk, "What the Heck is Happening Up North? Canadian Government Information Circa 2014," DttP: Documents to the People 42, no.1 (Spring 2014): 15-20, http://hdl.handle.net/10402/era.38740. 
6. Wakaruk, 2014; Amanda Wakaruk and Sam-chin Li, "The Evolution of Government Information Services and Stewardship in Canada," in Government Information in Canada: Access and Stewardship, ed. Amanda Wakaruk and Sam-chin Li (Edmonton, AB: University of Alberta Press, 2019): xiii-xxxi, https://www.uap.ualberta.ca /titles/924-9781772124446-government-information-in -canada.

7. "e-Petition 1116," Crown Copyright in Canada, https:// amandawakaruk.ca/crown-copyright-in-canada/e-pe tition-1116/; "Petitione-1116," HouseofCommonsofCanada, https://petitions.ourcommons.ca/en/Petition/Details ?Petition=e-1116.

8. Canada Department of Canadian Heritage, Response to Petition No. 421-01734, tabled December 4, 2017, https://www.ourcommons.ca/Content/ePetitions /Responses/421/e-1116/421-01734_PCH_E.pdf; Canada Department of Innovation, Science and Economic Development, Response to Petition No. 421-01734, tabled December 4, 2017, http://www.ourcommons.ca/Content /ePetitions/Responses/421/e-1116/421-01734_ISED_E .pdf.

9. "Statutory Review of the Copyright Act," Canada House of Commons Standing Committee on Industry, Science, and Technology, https://www.ourcommons.ca/Commit tees/en/INDU/StudyActivity?studyActivityId=9897131; "Crown copyright in Canada," https://amandawakaruk .ca/crown-copyright-in-canada/.

10. House of Commons Canada Standing Committee on Industry, Science and Technology, Statutory Review of the Copyright Act, Evidence, 42 Parl., 1st sess., October 29, 2018, https://www.ourcommons.ca/DocumentViewer/en /42-1/INDU/meeting-134/evidence.

11. Statutory Review of the Copyright Act, Evidence, May 9 and May 31, 2018, https://www.ourcommons.ca/Doc umentViewer/en/42-1/INDU/meeting-111/evidence and https://www.ourcommons.ca/DocumentViewer /en/42-1/INDU/meeting-119/evidence.

12. Statutory Review of the Copyright Act, Evidence, May 29, 2018, https://www.ourcommons.ca/DocumentViewer/en 142-1/INDU/meeting-118/evidence; House of Commons Canada Standing Committee on Industry, Science and Technology, Statutory Review of the Copyright Act, Brief submitted by the Canadian Association of Research Libraries, April 24, 2018, https://www.ourcommons.ca /Content/Committee/421/INDU/Brief/BR10003061 /br-external/CanadianAssociationOfResearchLibraries -e.pdf; House of Commons Canada Standing Committee on Industry, Science and Technology, Statutory Review of the Copyright Act, Brief submitted by the Canadian Association of Law Libraries, May 11, 2018, https:// www.ourcommons.ca/Content/Committee/421/INDU /Brief/BR10269423/br-external/CanadianAssociation OfLawLibraries01-e.pdf; House of Commons Canada Standing Committee on Industry, Science and Technology, Statutory Review of the Copyright Act, Report 16 (June 3, 2019): 46, https://www.ourcommons.ca/Con tent/Committee/421/INDU/Reports/RP10537003/in durp16/indurp16-e.pdf.

13. Statutory Review of the Copyright Act, Report 16, 45.

14. Statutory Review of the Copyright Act, Report 16, 46.

15. The Creative Commons attribution license (CC BY) is becoming the global standard for works that must retain copyright controls but can be widely distributed and reused. The CC BY license is currently used at the municipal level in multiple Canadian cities, by governments in Australia, Austria, Chile, Greece, India, Indonesia, Italy, Netherlands, New Zealand, Russia, and Spain, the European Commission, and various intergovernmental organizations.

16. Statutory Review of the Copyright Act, Report 16, 46.

17. Statutory Review of the Copyright Act, Report 16, 153-59.

18. "Case in Brief, Keatley Surveying Ltd. v. Teranet Inc.," Supreme Court of Canada, https://www.scc-csc.ca/case -dossier/cb/2019/37863-eng.aspx.

19. Interestingly, the court appears to accept historical justifications for Crown copyright, citing academic articles by Elizabeth Judge even though that author rejected the validity of those justifications, as noted in Luanne Freund and Elissa How, "The Quagmire of Crown Copyright: Implications for Reuse of Government Information," Canadian Law Library Review 40, no. 4 (2015): 13.

20. Jeremy de Beer, "Can the Government Get Your Copyright? 'The Supreme Court of Canada Says 'Yes', ipkitten (blog), October 4, 2019, http://ipkitten.blogspot.com /2019/10/guest-post-can-government-get-your.html?m=1.

21. An Act to Amend the Copyright Act (Crown copyright), Canada House of Commons, C-440, 42 Parl., 1st sess., (2019), https://www.parl.ca/LegisInfo/BillDetails.aspx ?Language=E\&billId=10395944\&View=10 and C-209, 43 Parl., 1st. sess., (2020), https://www.parl.ca/LegisInfo /BillDetails.aspx?Language=E\&billId=10614052; Cable Public Affairs Channel, "NDP MP Brian Masse Outlines Proposal to Modernize Crown Copyright Laws," Press conference, April 10, 2019, https://www.cpac.ca /en/programs/headline-politics/episodes/65968286/. 
22. An Act to Amend the Copyright Act, Canada House of Commons, C-442, 34 Parl., 3rd sess., (1993), https:// drive.google.com/file/d/1lp1XKC9FgUWO8xhVn _U0a7lVvOirDECU/view.

23. Canadian Federation of Library Associations, "Next steps in advancing changes to Crown copyright," August 2, 2019, http://www.carl-abrc.ca/wp-content/uploads/2019 /08/Crown_copyright_letter_EN_final_with_logos.pdf.
24. Canada Office of the Prime Minister, Minister of Innovation, Science and Industry Mandate Letter, December 13, 2019, https://pm.gc.ca/en/mandate-letters/minister-inno vation-science-and-industry-mandate-letter; Minister of Canadian Heritage Mandate Letter, December 13, 2019, https://pm.gc.ca/en/mandate-letters/minister-canadian -heritage-mandate-letter. 